\title{
A Correlational Study: Reading Comprehension and the Most Prevalent Intelligence Among Pre-Service English Teachers
}

\author{
Evi Puspitasari ${ }^{1 *}$, Khoirunnisa Isnani $^{2}$ \\ ${ }^{1,2}$ English Language Education Department, Universitas Muhammadiyah Yogyakarta \\ *Corresponding author. Email: evipuspitasari@fpb.umy.ac.id
}

\begin{abstract}
In the English as a Foreign Language (EFL) context, multiple intelligences play an essential role for teachers to decide the types of support they can give to enhance students' linguistic ability, including reading. The researchers determined the most dominant multiple intelligence among English Department students through this quantitative study and confirmed the correlation between intelligence and reading comprehension. To achieve those aims, 111 senior students at the department took part as the research respondents by filling in a questionnaire adopted from Mckenzie (1999). The survey result showed that in the majority, students are existential. Continuing the process, using ten questions from the questionnaire that focused on intelligence, the students' existential was measured.Meanwhile, the reading comprehension level was identified from a reading section of the TOEFL-like test that the students did in one of the classes. The data were analyzed using descriptive statistics and Pearson Product Moment Correlation (r) through SPSS version 20. The results revealed 37 intelligently existential students' intelligence was at the high level (3.2-4.2), and students' reading comprehension was at the fair level (396.68-503.35). The result also showed that the significance value was $0.009<0.05$, and the correlation value (r-value) was 0.421 . There was a positive correlation between existential intelligence as students' most dominant multiple intelligence and their reading comprehension at a moderate level.
\end{abstract}

Keywords: Multiple intelligences, existential intelligence, reading comprehension, an EFL context

\section{INTRODUCTION}

Discussing intelligence in an educational context cannot be separated from students' learning styles. Intelligence is defined as an ability to solve a problem and a composite of different skills and aptitudes [see 1]. At the same time, learning strategies are complex procedures undertaken by students in fulfilling various tasks [see 2]. Gardner mentioned types of intelligences which are verbal-linguistic which links to students' ability in using words effectively and creatively in speaking and writing; logical-mathematical which shows competence in numbering and thinking abstractly, conceptually and logically; spatial-visual which highlights an ability in comprehending and imitating models in detail; musical which regards to competence in identifying converting, and performing rhythm, melody, and tone of music; kinesthetic which captures a capability in expressing feeling using body movement; interpersonal which deals with an ability in handling different mood, motivation, and feeling to others; intrapersonal which is related to an ability to understanding themselves well; naturalist which an ability to classify and category flora, fauna, and another part of the world; and existential which is about understanding the meaning of human life from broad context or an ability to challenge the profound question about role of human existence. Meanwhile, R. Oxford [3] classified learning styles into cognitive, meta-cognitive, compensatory, social, memory-related, and practical strategies. Even though both are understood differently by experts, they work hand in hand in students' learning. In parallel, some researchers [see 4, 5, 6] gave empirical evidence that learning strategies correlate with intelligence.

Understanding students' type of intelligence in classrooms is imperative for teachers. Sufficient knowledge of intelligence will help teachers decide what and how to give the materials to the students, which optimizes the teaching and learning process. M. Yaumi, S. F. S. Sirate, and A. A. Patak [7] highlighted the importance of giving teachers training to introduce the integration of intelligence in their teaching performance. As a result, the training successfully helped the teachers to implement student-centered learning by bringing various learning strategies in so that students can select based on their preferences. Besides increasing teachers' performance, integrating students' intelligence in teaching and learning also benefits students. K. H. Hajhasemi, N. J. Caltabiano, N. Anderson, and S. A. Tabibzadeh [8] revealed that accommodating students' multiple intelligences could give students a meaningful learning experience and increase their learning motivation. 
In language learning, the skill frequently discussed with intelligence is reading since both deal with students' cognitive competence. Gardner [1] mentioned that intelligence follows cognitive ability, and reading is known as a cognitive process. When reading, students' minds actively digested the new information and related it to what they previously knew. Some information may be deleted, revised, or added by the new one depending on their comprehension of the text. Referring to C. Snow [9], one of the reading comprehension components is abilities that fall into three: attention, memory, and inferencing. All of them are executed through students' mental or cognitive processes.

Several experts have investigated students' intelligence and reading comprehension in English as a foreign language (EFL). The first research was done by A. A. Zarei and N. S. Afshar [10], which aimed to identify types of students' intelligence that can predict students reading comprehension. Involving $240 \mathrm{EFL}$ students as research respondents, they used the TOEFL reading subtest and Multiple Intelligences (MI) questionnaire for data collection. The result showed that students' musical, interpersonal, kinesthetic, and logical intelligence could predict their reading comprehension.

M. K. Sabet and M. M. Kiaee [11] explored the relationship between MIs of a group of EFL learners, medical students in this case, and their reading comprehension ability. A descriptive expo-facto was employed as the research design and involved 157 students whose English was in the intermediate level. It was known that there is a weak correlation between students' MI and reading comprehension. Besides, the research also presented the most ordinary intelligence the students possessed, which was verballinguistic.

The third investigation about the relationship between reading comprehension and multiple intelligence is from $\mathrm{S}$. Celik [12]. Aiming to compare numerous intelligence-based activities and tasks to the common ones to enhance students' reading comprehension, the researcher used a quasiexperimental study involving $95 \mathrm{EFL}$ students. The result indicated that the activities and tasks were designed by considering students' multiple intelligences were more effective than ones who were not.

Based on the review, a gap seems to exist. It is undeniably true that the previous studies all portrayed positive interrelation between multiple intelligence and students' reading comprehension. However, research capturing the relationship of the two variables that focuses on pre-service English teachers is still absent. In fact, as future teachers who teach English, they will teach reading to their students. To effectively teach the students, their pedagogical knowledge and reading skills should be firm. Assisting pre-service English teachers to improve their English need activities, tasks, and other teaching components that accommodate their type of intelligence, making the rationale of doing this research legit. Therefore, this research has formulated two questions: (1) What is the prevalent intelligence possessed by the pre-service English teachers; (2) What is the correlation between the prevalent intelligence and reading comprehension among pre-service English teachers. Specifically, the hypothesis (H1) for the second research question is "there is a correlation between the prevalent intelligence and reading comprehension among the preservice English teachers.

\section{RESEARCH METHOD}

This research utilized a survey to answer the first question and a correlational design to unveil the relationship between two variables standing under a quantitative study. The prevalent intelligence and reading comprehension. 111 senior pre-service English teachers in one English teacher training center filled a multiple intelligence questionnaire by McKenzie [13]. The questionnaire consisted of 90 items for nine intelligence types. Then, the researchers simplified the questionnaire into 27 items by choosing items that matched the research questions and the context of pre-service teachers. Furtherly, it showed the prevalent intelligence, and items were employed to assess the level. Before distributing the questionnaire, the items were translated into Indonesian and evaluated by three experts to check the language accuracy. The result of the instrument validity was analyzed using Gregory's formula Retnawati [14], and the score was 1, more significant than 0.8 , which was categorized into high validity. Besides, the result of the reliability score was 0.818 , and classified into highly reliable that was calculated by Cronbach's Alpha coefficient [see 15]. The questionnaire was good since the validity and reliability results were high category. From 111 respondents, 37 students with a common intelligence were obtained to do a TOEFL-like reading subtest.

Data for the first research question was analyzed using descriptive statistics. According to [15], the researcher will use descriptive statistics to describe and present the data by indicating central tendency (means, modes, medians). Then, the researcher categorized students' most common type of intelligence into three levels using Supranto's [16] formula.

$$
c=\frac{X n-X 1}{k}
$$

Description

$\mathrm{c}=$ The range prediction (class width, class size, class length)

$\mathrm{k}=$ The number of classes that researcher wants

$\mathrm{Xn}=$ The maximum score of a variable

$\mathrm{X} 1$ = The minimum score of a variable

In detail, the category of students' most dominant intelligence was shown as follows: 
Table 1. Category of Students' Prevalent Intelligence

\begin{tabular}{|c|c|}
\hline Score Range & Description \\
\hline $1-2$ & Low \\
\hline $2.1-3.1$ & Moderate \\
\hline $3.2-4.2$ & High \\
\hline
\end{tabular}

The second research question, pre-service English teachers' reading comprehension in TOEFL-like, was answered using descriptive statistical analysis. The researcher described the students' reading comprehension in TOEFLlike by seeing the mean. Then, the researchers also categorized students reading comprehension into three levels that used Supranto's formula above with a minimum score of 290 , the maximum score of 610 , and the interval value of 106.67. There were poor, fair, and good categories.

Table 2. The Category of Students' Reading TOEFL-Like Score

\begin{tabular}{|c|c|}
\hline Score Range & Description \\
\hline $290-396.67$ & Poor \\
\hline $396.68-503.35$ & Fair \\
\hline $503.36-610.03$ & Good \\
\hline
\end{tabular}

Next, the data were analyzed using the inferential statistic. Since this research was explanatory correlation design, the researcher used Pearson Product Moment Correlation $(r)$ to find a correlation between the pre-service English teachers' prevalent intelligence and their reading comprehension in TOEFL using SPSS program version 20. According to Cohen, Manion, and Morrison [15], inferential statistics is research attempting to determine the outcome based on data gathered. Before it, the researcher tests the normality and linearity of the data. Normality test is used whether the participants are from the same proficiency. The researchers also tested the linearity of the variables to observe whether the variables were significantly linear.

The correlation of the variables uses Pearson Product Moment, in which the coefficient statistics are correlated at $\rho$ $<0.05$. The five criteria of correlation level are seen below:

Table 3. The Correlation Criteria Value

\begin{tabular}{|c|c|}
\hline Interval of Coefficient & Correlation Level \\
\hline $0.00-0.199$ & Very Low \\
\hline
\end{tabular}

\begin{tabular}{|c|c|}
\hline $0.20-0.399$ & Low \\
\hline $0.40-0.599$ & Moderate \\
\hline $0.60-0.799$ & Strong \\
\hline $0.80-1.000$ & Very Strong \\
\hline
\end{tabular}

\section{RESULTS AND DISCUSSION}

In this part, the researchers focused on presenting the research results after the data were analyzed.

\subsection{The Students' Prevalent Intelligence}

The researchers analyzed the data using the descriptive statistic in SPSS program version 20 to identify the students' prevalent intelligence. The mean score of all intelligence is presented in Table 4.

Table 4. Mean score of each intelligence type

\begin{tabular}{|l|l|c|}
\hline No. & \multicolumn{1}{|c|}{$\begin{array}{c}\text { Multiple Intelligence } \\
\text { Types }\end{array}$} & Mean Score \\
\hline 1. & Verbal/linguistic & 8.40 \\
\hline 2. & Logical/mathematical & 9.05 \\
\hline 3. & Spatial/visual & 8.51 \\
\hline 4. & Musical & 8.43 \\
\hline 5. & Bodily/kinesthetic & 9.21 \\
\hline 6. & Interpersonal & 8.11 \\
\hline 7. & Intrapersonal & 9.09 \\
\hline 8. & Naturalist & 8.47 \\
\hline $\mathbf{9 .}$ & Existential & $\mathbf{9 . 4 6}$ \\
\hline
\end{tabular}

Based on Table 4, the highest mean is existential intelligence, and 37 students possessed the prevalent intelligence. In detail, 37 students found that the mean score of students' prevalent intelligence is 3.35, as shown in Table 5 .

Table 5. Students' Prevalent Intelligence

\begin{tabular}{|c|c|c|c|c|c|}
\hline No. & $\begin{array}{l}\text { Score } \\
\text { range }\end{array}$ & $\begin{array}{c}\text { The } \\
\text { category of } \\
\text { students' } \\
\text { prev. } \\
\text { intelligence } \\
\text { level }\end{array}$ & $\begin{array}{l}\text { Fre } \\
\text { que } \\
\text { ncy }\end{array}$ & $\begin{array}{c}\text { Perce } \\
\text { nt } \\
(\%)\end{array}$ & $\begin{array}{l}\text { The } \\
\text { mean } \\
\text { score } \\
\text { of } \\
\text { stude } \\
\text { nts' } \\
\text { preva } \\
\text { lent } \\
\text { intelli } \\
\text { gence }\end{array}$ \\
\hline 1. & $1-2$ & Low & 1 & 2.7 & \multirow{4}{*}{3.35} \\
\hline 2. & $2.1-3.1$ & Moderate & 7 & 18.9 & \\
\hline 3. & $3.2-4.2$ & High & 29 & 78.4 & \\
\hline \multicolumn{3}{|c|}{ Total } & 37 & 100.0 & \\
\hline
\end{tabular}


Based on students' prevalent intelligence category, the mean score of 3.35 belongs to the "high" category (3.2-4.2). Most students have high existential intelligence as their prevalent intelligence meaning that they enjoyed a discussion about life and figured their role in life.

\subsection{The Correlation of Pre-service English Teachers' Prevalent Intelligence to Reading Comprehension}

Before assessing the possible correlation between variable 1 and variable 2 using an inferential statistic, the level of students' comprehension needs to be identified. The data shows that the TOEFL-like reading subtest showed that the minimum score was 290 and the maximum score was 610 . Besides, the researchers categorized students' reading TOEFL-like scores into three categories: poor, fair, and good. Table 6 presents the detail of students' reading comprehension results.

Table 6. Students' Reading Comprehension Score

\begin{tabular}{|c|c|c|c|c|c|}
\hline No. & $\begin{array}{l}\text { The } \\
\text { range } \\
\text { score }\end{array}$ & $\begin{array}{c}\text { The } \\
\text { Categor } \\
y\end{array}$ & Freq & $\begin{array}{c}\text { Perce } \\
\text { nt } \\
(\%)\end{array}$ & $\begin{array}{c}\text { The } \\
\text { mea } \\
\mathrm{n} \\
\text { scor } \\
\mathrm{e}\end{array}$ \\
\hline 1. & $\begin{array}{l}290- \\
396.6 \\
7\end{array}$ & Poor & 4 & 10.8 & \\
\hline 2. & $\begin{array}{l}396.6 \\
8- \\
503.3 \\
5\end{array}$ & Fair & 30 & 81.0 & $\begin{array}{c}439 . \\
81\end{array}$ \\
\hline 3. & $\begin{array}{l}503.3 \\
6- \\
610.0 \\
3\end{array}$ & Good & 3 & 8.2 & \\
\hline \multicolumn{3}{|c|}{ Total } & 37 & 100.0 & \\
\hline
\end{tabular}

The result showed that the mean score of students' reading comprehension is 439.81, categorized into the fair level. Then, the table described that most pre-service English teachers have fair reading comprehension in the TOEFL-like subtest. Afterward, the normality and linearity test result showed that the normality significance value of students' prevalent intelligence variable was 0.236, and the significance value of the reading comprehension variable was 0.399. It means that all variables distribution were normal since the significance values were more significant than 0.05 . Moreover, the linearity significance value was 0.013 (lower than 0.05 ), with the F-Linearity value was 7.180. It means that the result was significant, and then the variables were linear to be applied to its relation model.
The correlation test assessed the possible correlation between the prevalent intelligence and reading comprehension in the next step. Then, the correlation between two variables was identified using Pearson Product Moment Correlation (r), and the result was presented in Table 7.

Table 7. Result of Correlation Test

\begin{tabular}{|l|l|l|l|l|}
\hline $\begin{array}{c}\text { Independ } \\
\text { ent } \\
\text { Variable } \\
(\mathrm{X})\end{array}$ & $\begin{array}{c}\text { Depende } \\
\text { nt } \\
\text { Variable } \\
(\mathrm{Y})\end{array}$ & $\mathrm{N}$ & $\begin{array}{c}\text { Person } \\
\text { Correla } \\
\text { tion }\end{array}$ & Sig. \\
\hline $\begin{array}{l}\text { The } \\
\text { prevalent } \\
\text { intelligen } \\
\text { ce }\end{array}$ & $\begin{array}{l}\text { Reading } \\
\text { Compreh } \\
\text { ension }\end{array}$ & 37 & 0.421 & 0.009 \\
\hline
\end{tabular}

The result showed that the Pearson correlation value ( $\mathrm{r}$ value) was 0.421 , and the significance value was 0.009 with a sample size $(\mathrm{N})$ was 37 . The hypothesis testing was analyzed by comparing significance values ( $\rho$-value). According to L. Cohen, L. Manion, and K. Morrison [15], "coefficient statistics are statistically significantly correlated at the $\rho<0.05$ levels" (p. 345). The finding above showed that the significant value ( $\rho$-value) was 0.009 , lower than 0.05 . It means that there is a positive and significant correlation between students' existential intelligence as their most dominant multiple intelligence and their reading comprehension, and then alternative hypothesis (H1) was accepted. Moreover, the correlation proportion can be seen from the Pearson correlation value (r-value). The table showed that the r-value was 0.421. Based on Sugiono's [17] criteria of correlation level (see table 8), 0.421 was on a moderate level (0.40-0.599). There is a correlation between students' prevalent intelligence and their reading comprehension at a moderate correlation level.

Moreover, the correlation between existential intelligence and students' reading comprehension was caused by an existential person thinking critically in answering a question. This result was supported by Logsdon's [18] statement that existential people think critically on the nature of existence and the reality of this universe. It can be assumed that existential people use their critical thinking ability to consider all their curiosity. According to Duron, Limbach, and Waugh (2006), critical thinking is the brain's ability “to analyze and evaluate information (p. 160). Besides, reading comprehension is also the brain's ability to analyze the authors' meaning of the text. Hence, existential people think critically about examining and evaluating information that is also used in reading comprehension.

Furthermore, these variables are related because both are the same as a cognitive process in the brain. According to $\mathrm{K}$. Hajhashemi, K. Akef, and N. Anderson [19], reading is a cognitive process that uses the brain's ability to construct an author's meaning. It can be assumed from the definition. There is a brain role in reading activity which means that 
someone's intelligence is related to their reading comprehension. Thus, students' reading comprehension in TOEFL-like scores was influenced by their existential intelligence.

The finding of this research was supported by Sabet and Kiaee's [11] study that found a positive correlation between students' intelligence and their reading comprehension proficiency, but the strength of correlation was weak. In other research, F. Fahim, F. Bagherkazemi, and M. Alemi [19] found that some intelligence types of multiple intelligences are correlated with reading TOEFL and IELTS. However, their research revealed that only linguistic and logical intelligence was associated with reading TOEFL. Besides, this research found that existential intelligence as students' most dominant multiple intelligence positively correlated with their reading comprehension.

\section{CONCLUSION}

In conclusion, the data showed that the prevalent intelligence of pre-service English teachers is existential intelligence, with 9.46 as the mean score, which is the highest of all intelligence. It shows that most senior pre-service English teachers in that institution enjoyed talking about life, understanding their goals in life well, and paying much attention to nature and the universe of existence. Besides, they also believed that religion was an essential aspect for them. For the level, their existential intelligence was high, with a mean score of 3.55. Regarding the reading comprehension level, the data revealed that the pre-service English teachers' mean score for reading comprehension was 439.81, which was fair. Through the inferential statistical analysis, it was noticeable that the two variables were moderately correlated.

\section{REFERENCES}

[1] H. Gardner, Intelligence reframed: Multiple intelligences for the twenty-first century, New York: Basic Books, 1983.

[2] J. M. O'Malley and A. U. Chamot, Learning strategies in language acquisition. Cambridge: Cambridge University Press, 1990.

[3] R. Oxford. Language learning strategies: what every teacher should know. Boston: Heinle \& Heinle, 1990.

[4] A. Sulaiman, Wu, S., and A. M. Alotaibi, The learning styles and multiple intelligences of EFL college students in Kuwait. International education studies, 2018, 11(30): 38-47.

[5] S, Şener, and Ç. Ayten, An investigation between multiple intelligences and learning styles, Journal of Education and Training Studies, 2018, 6(2): 125 - 132.

[6] A.A. Ansarin and S. P. Khotibi, The relationship between multiple intelligences and language learning strategies and gender, 2017, 11(5): 84 .

[7] M. Yaumi, S.F.S. Sirate, and A.A. Patak, Investigating multiple intelligence-based instruction approach on performance improvement of Indonesian elementary madrasah teachers, SAGE Open, 2018: 1-10.
[8] K. Hajhashemi, N. Caltabiano, N., Anderson, and S. Tabibzadeh, Multiple intelligences, motivations and learning experience regarding video-assisted subjects in a rural university, International Journal of Instruction, 2018, 11(1):167-182.

[9] S. Catherine, Reading for Understanding: Toward an R\&D program in reading comprehension. California: RAND Corporation, 2002.

[10] A. A. Zarei and NS. Afshar, Multiple intelligences as predictors of reading comprehension and vocabulary knowledge. Indonesian Journal of Applied Linguistics, 2014, 4(1): 23-38.

[11] M. K. Sabet and M. M. Kiaee, The relationship between multiple intelligences and reading comprehension of EFL learners across genders, International Journal of Education \& Literacy Studies, 2016, 4(1): $74-81$.

[12] Celik, S., Intelligence differences and mediation factors: sequential explanatory study of improvement of EFL undergraduate students' reading comprehension skills, International Journal of Language Education, 2019, 3(2): 128-145.

[13] W. McKenzie, Multiple intelligences survey, Retrieved from http://surfaquarium.com/MI/MIinvent.htm, 1999.

[14] Retnawati, Validitas, reliabillitas, \& karakter butir (panduan untuk peneliti, mahasiswa, dan psokimetrian). Yogyakarta: Parama Publishing, 2016.

[15] L. Cohen, L, Manion, and K. Morrison, Research methods in education. $7^{\text {th }}$ ed. London: Routledge, 2011.

[16] J. Supranto, Statistik: Teori dan aplikasi, Jakarta: Erlangga, 2000:64.

[17] Sugiono. Metode penelitian kuantitatif kualitatif dan R\&D, Edisi ke 14, Bandung: Alfabeta, 2011.

[18] A.Logsdon, Understanding the existential learning style, Verywell, retrieved from https://www.verywell.com/understanding-theexistential-learning-style-2162779, 2016.

[19] K, Hajhashemi, K, Akef, and N, Anderson, The relationship between multiple intelligences and reading proficiency of Iranian EFL students, World Applied Sciences Journal, 2012, 19(10): 1475 1483.

[20] F. Fahim, F. Bagherkazemi, and M. Alemi, The relationship between test takers "critical thinking ability and their performance on the reading section of TOEFL, Journal of Language Teaching and Research, 2010, 1(6): $830-837$. 